\title{
PREDIKSI NILAI BATAS ELASTISITAS BAJA KONSTRUKSI DENGAN UJI KEKERASAN BRINELL DAN VICKERS
}

\author{
Vinan Viyus ${ }^{1}$, Khambali ${ }^{2}$, Bambang Hertomo ${ }^{3}$ \\ 1,2,3 Jurusan Teknik Mesin Politeknik Negeri Malang \\ ${ }^{1}$ vin40@rocketmail.com
}

(Artikel diterima: Februari 2020, direvisi: April 2020, diterima untuk terbit: Juli 2020)

\begin{abstract}
Abstrak - This study aimed to determine the correlation value against the value of hard carbon steel with elasticity it. This is done by determining the formula formulation in the form of the regression equation $\mathrm{Y}=\mathrm{AX} 1+\mathrm{BX}$. Data taken from the sample used in the form of a cylindrical rod test specimens and the steel plate. Severity using the Brinell test, whereas withdrawal using tensile testing machine. The results were obtained for cylindrical steel $\mathrm{Y}=2,41 \mathrm{X} 1-0,4347 \mathrm{X} 2$ and for specimens of steel plate (flat) $\mathrm{Y}=2,35 \mathrm{X} 1-0,534 \mathrm{X} 2 . \mathrm{Y}$ is the value of the rigidity, and $\mathrm{X} 1$ is hardness of steel. While $\mathrm{X} 2$ arises from material stretch factor. Probability influence of workmanship and style fluctuate respectively 0,4347 and 0,534 is much larger than 0.05 (a standard which is commonly used). This means that the regression coefficient is not significantly different effect. Decrease in strength may be due to the loss of influence of the stress concentration occurs. In addition it could also be due to the configuration of the carbon forming constituents uneven in areas experiencing strain due to the with drawalprocess
\end{abstract}

Kata kunci: cylindrical steel, steel plate, stress, strain, elasticity

\section{Pendahuluan}

Dalam penggunaan bahan teknik secara tepat, harus mengetahui sifat-sifat ataupun perilaku dari bahan tersebut untuk dipergunakan. Sifat-sifat tersebut sangat banyak, dan dapat ditinjau dari berbagai bidang keilmuan. Tidak harus semua sifat tersebut diatas perlu dipertimbangkan dalam memilih bahan untuk suatu keperluan hal ini tergantung dari keperluannya. Dalam bidang Teknik Mesin selain sifat kimia (terutama sifat tahan korosi), sifat termal dan sifat fisik, juga sifat mekanis.

Diantara sifat mekanis material yang penting selain kekuatan dan kekerasan adalah kekakuannya (stiffness). Selama ini kekakuan material, selain didasarkan atas pengujian tarik di daerah elastis juga biasa dilakukan dengan pengujian bending. Kedua pengujian tersebut hanya bisa dilakukan di laboratorium tertentu dan biayanya relatif lebih mahal. Untuk keperluan praktis terkadang kita perlu mencari terobosan yang lebih memudahkan. Ada kesamaan parameter antara keras dengan kekuatan dan kekakuan. pengembangan pengetahuan bahan teknik dan pemanfaatannya lebih lanjut.

Penelitian ini dimaksudkan untuk melihat korelasi nilai kekerasan suatu material teknik dengan nilai batas elastisitas material tersebut. Data diambil dari sampel berupa spesimen uji dari bahan baja karbon rendah. Pengujian dilakukan dengan uji keras metode Brinell kemudian dilanjutkan dengan uji tarik. Data yang diperoleh kemudian diolah. Formulasi yang diperoleh selanjutnya akan digunakan untuk menghitung dan mengestimasi nilai batas elastisitas baja karbon berdasarkan harga kekerasan Brinell yang didapatkan.

\section{Tinjauan Pustaka}

\section{A. Sifat Mekanis Logam}

Sifat mekanis merupakan kemampuan atau kelakuan logam itu menahan beban yang dikenakan padanya, baik pembenahan statis atau dinamis pada suhu biasa, suhu tinggi ataupun suhu dibawah $0^{\circ} \mathrm{C}$. Sering kali bila suatu bahan mempunyai sifat mekanis yang baik tetapi kurang baik pada sifat yang lain, maka diambil langkah untuk menanggulangi kekurangannya tersebut. Beberapa sifat mekanis yang penting antara lain :

- Kekuatan (strength): Menyatakan kemampuan bahan untuk menerima tegangan tanpa menyebabkan patah atau kerusakan pada bahan. Kekuatan ini ada beberapa macam, tergantung pada jenis beban yang bekerja, yaitu kekuatan tarik, tekan, geser, torsi dan gengror.

- Kekerasan (hardness): Didefinisikan sebagai kemampuan bahanterhadap deformasi praktis bereng pembebanan setempat pada permintaan berupa penggoresan, pengikisan (abrasi), identasi atau penetrasi. Sifat ini berkaitan erat dengan sifat bahan aus. Kekerasan juga mempunyai korelasi dengan kekuatan.

- Kekakuan (stiffness): Menyatakan kemampuan bahan untuk menerima beban tanpa mengakibatkan terjadinya deformasi atau defleksi. Seringkali kekakuan lebih penting daripada kekuatan.

Hubungan Tegangan dan Regangan (Hukum Hooke)

Pada bahan yang mengikuti hukum Hooke, beban yang bekerja $P_{\mathrm{A}}$ dan $P_{\mathrm{B}}$ akan menyebabkan tegangan $s_{\mathrm{A}}$ dan $s_{\mathrm{B}}$, dan perbandingan dua nilai menjadi konstan, yaitu:

$$
\frac{s_{A}}{\varepsilon_{A}}=\frac{s_{B}}{\varepsilon_{B}}=\text { konstan }
$$

Konstanta ini sekarang dikenal sebagai modulus elastisitas atau modulus Young Modulus Young dinotasikan dengan simbol $E$ dan berlaku untuk tarik atau tekan, dinyatakan dengan persamaan:

$$
E=\frac{\text { tegangan }}{\text { regangan }}=\frac{s}{\varepsilon}
$$


Secara fisik, modulus elastisitas adalah merupakan ukuran kekakuan (stiffness) bahan terhadap respon pada beban yang bekerja dan menunjukkan sifat tertentu bahan. Bahan kaku didefinisikan sebagai sifat bahan yang mampu bertahan pada tegangan tinggi tanpa terjadi regangan yang besar.

\section{B. Kekerasan Material}

Kekerasan material didefinisikan sebagai ukuran ketahanan bahan terhadap deformasi plastis lokal berupa penekanan atau goresan kecil. Kekerasan merupakan sesuatu sifat mekanik bahan yang penting karena sangat menentukan ketahanan terhadap keausan, dan kemudahan dalam proses pengerjaan. [6].

\section{Uji Keras Metode Brinell}

Pada metode Brinell, sebuah bola baja yang telah di keraskan atau carbida tungsten ditekankan pada permukaan benda uji yang rata dengan gaya $F$ tertentu. Pada saat penekanan, beban di pertahankan konstan selama beberapa detik (antara 10 sampai 30 detik)..

Setelah penekanan selesai, diameter bekas penekanan yang berbentuk segmen (tembereng) bola di ukur. Nilai kekerasan Brinell dinyatakan dengan:

$$
H B=\frac{\text { Gaya }}{\text { LuasBekasPenekanan }}
$$

Luas bekas penekanan berbentuk sigmen ( tembereng ) bola Harga kekerasan Brinell dirumuskan sebagai berikut:

$$
H B=\frac{2 F}{\pi D\left(D-\sqrt{D^{2}-d^{2}}\right)}
$$

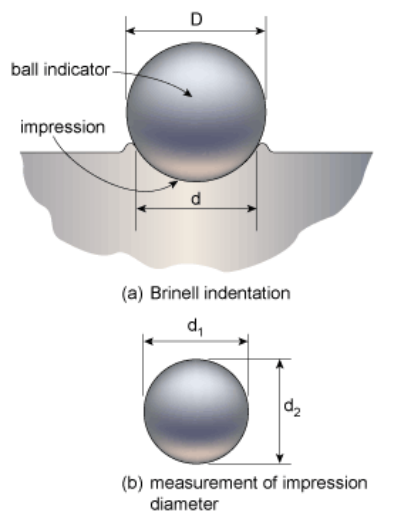

Gambar 1. Penekanan bola baja pada metode Brinell (Sumber. Http://www.twi.co.uk)

\section{Uji Keras Metooda Vickers}

Uji keras metoda Vikcers dikenal juga sebagai Diamond Pyramid Hardness test (DPH). Uji kekerasan vickers menggunakan indentor piramida intan, besar sudut antar permukaan piramida intan yang saling berhadapan adalah 136 derajat .

$$
\mathrm{Hv}=\frac{2 \mathrm{~F} \mathrm{Sin}{ }^{\circ} 2}{\mathrm{D}^{2}}=\frac{1,8554 \mathrm{~F}}{\mathrm{D}^{2}}
$$

$\mathrm{HV}=$ Angka kekerasan Vickers

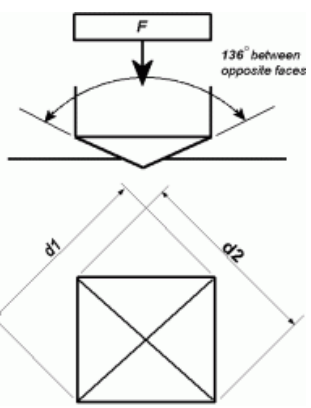

Gambar 2. Penekanan metode Vikers

\section{E. Pengujian Tarik}

Uji Tarik yaitu penarikan suatu benda uji sampai putus secara beraturan tanpa adanya kejutan. Kecepatan penambahan panjang (perpanjangan) harus kecil agar didapatkan hasil yang benar. Gaya tarik dan perubahan panjang dari benda uji diukur dan kemudian dianalisa.

\section{Benda Uji Tarik}

Gambar 3a. menunjukkan suatu benda uji tarik (spesimen) yang berbentuk batang dengan luas permukaan yang sama dan beradius pada kedua ujungnya dan mempunyai diammeter lebih besar untuk tempat pencekaman.

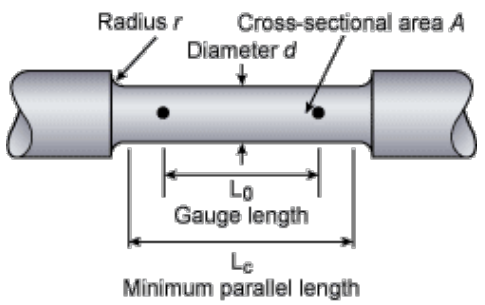

(a) Round cross section

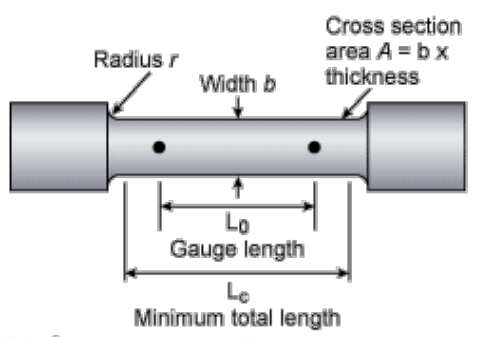

(b) Square cross section

Gambar.3 :Spesimen uji tarik

(Sumber Http://www.profesionaltesting.co.th)

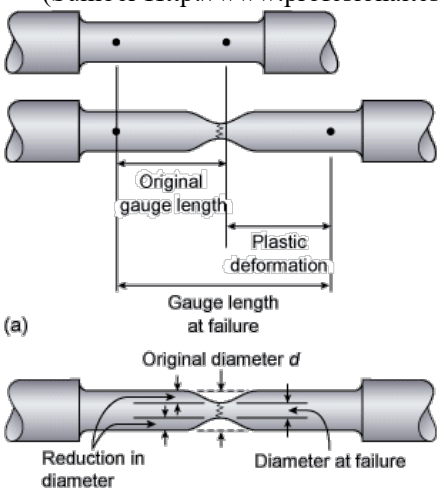

(b)

Gambar 4. Spesimen uji tarik setelah dilakukan penarikan (Sumber Http://www.profesionaltesting.co.th) 
Keterangan:

- $\quad \mathrm{L}_{\mathrm{o}}=$ panjang mula-mula

- $\quad \mathrm{L}_{\mathrm{I}}=$ panjang setelah patah (jika kedua bagian disatukan)

- $\quad \mathrm{A}_{\mathrm{o}}=$ Luas penampang mula-mula (dengan $\mathrm{d}_{\mathrm{o}}$ )

- $\quad \mathrm{A}_{1}=$ Luas penampang pada bagian yang patah

Dimensi yang terpenting adalah panjang $\mathrm{L}_{\mathrm{o}}$ dan diameter $\mathrm{d}_{\mathrm{o}}$, dimana kedua dimensi ini mempunyai perbandingan yang tetap (proporsional).

\section{Metode Penelitian}

\section{A. Urutan Pengujian}

Pada specimen dilakukan uji keras terlebih dahulu baru kemudian dilakukan uji Tarik. Uji Keras yang dilakukan adalah metode Brinell.

\section{B. Model Spesimen}

Kedua pengujian tersebut di atas dilakukan menggunakan bahan spesimen Baja Silindris (BS) dan Baja Pelat (BP) sesuai standar yang umum digunakan (standarJIS), Masingmasing specimen dibuat dengan jumlah sepuluh specimen (110). Output yang diperoleh dari uji keras berupa gaya dan diameter tembereng bekas penekanan oleh indentor. Adapun dari uji tarik diperoleh gaya dan pertambahan panjang akibat penarikan, yang kemudian digunakan untuk menghitung tegangan tarik serta modulus elastisitas bahan tersebut.

\section{Rancangan Percobaan}

Rancangan percobaan adalah klasifikasi satu arah dengan sampel yang digunakan

Adapun persamaan yang digunakan:

$Y i j=\mu+\alpha i+\varepsilon i j$

Yij = nilai pengamatan ke $\mathrm{i}$ dalam kelompok $\mathrm{j}$

$\mu \quad=$ nilai rata-rata umum

$\alpha \mathrm{i}=$ pengaruh perlakuanke $\mathrm{i}$

cij = kesalahan percobaan pada perlakuan ke I ulangan ke j Output yang diperoleh berupa gaya dan pertambahan panjang akibat penarikan,

\section{Perolehan Data}

Output yang diperoleh dari uji keras berupa gaya dan diameter tembereng bekas penekanan oleh indentor. Adapun dari uji tarik diperoleh gaya dan pertambahan panjang akibat penarikan, yang kemudian digunakan untuk menghitung tegangan tarik serta modulus elastisitas bahan tersebut.

\section{Hasil Penelitian dan Pembahasan}

\section{A. Data Hasil Uji Tarik: Spesimen Baja Silindris}

Diameter Spesimen do $=8,0 \mathrm{~mm}$

Panjang Awal Lo $=80 \mathrm{~mm}$

Diameter Indentor $\quad \mathrm{D}=5 \mathrm{~mm}$
Tabel 1. Data Penelitian Baja Silindris

\begin{tabular}{|l|l|l|l|l|l|}
\hline \multirow{2}{*}{ Sp } & \multicolumn{4}{|l}{ Data yang diperoleh } \\
\cline { 2 - 6 } & \begin{tabular}{l}
$\mathbf{d}(\mathbf{m m})$ \\
\cline { 2 - 6 }
\end{tabular} & $\mathbf{F y}(\mathbf{N})$ & $\begin{array}{l}\Delta \mathbf{L}-\mathbf{y} \\
\mathbf{( m m})\end{array}$ & Fu (N) & $\Delta \mathbf{L - u}(\mathbf{m m})$ \\
\hline 2 & 1,32 & 13600 & 5,23 & 17500 & 7,30 \\
\hline 3 & 1.30 & 13700 & 5,25 & 17300 & 8,10 \\
\hline 4 & 1,20 & 13400 & 6,20 & 17700 & 7,50 \\
\hline 5 & 1,10 & 14000 & 4,90 & 16300 & 7,80 \\
\hline 6 & 1,28 & 14400 & 4,90 & 16400 & 7,00 \\
\hline 7 & 1,30 & 13200 & 5,40 & 16600 & 8,00 \\
\hline 8 & 1,30 & 13600 & 5,35 & 17900 & 8.30 \\
\hline 9 & 1,20 & 13500 & 4,90 & 17300 & 8,00 \\
\hline 10 & 1,20 & 13600 & 6,25 & 17700 & 6,85 \\
\hline Rata2 & $\mathbf{1 , 2 4}$ & $\mathbf{1 3 6 4 0}$ & $\mathbf{5 , 3 8}$ & $\mathbf{1 7 1 8 0}$ & $\mathbf{7 , 5 8}$ \\
\hline
\end{tabular}

Tabel 2. Data Penelitian Baja Baja Pelat

\begin{tabular}{|c|c|c|c|c|c|}
\hline \multirow{2}{*}{ Sp } & \multicolumn{5}{|c|}{ Data yang diperoleh } \\
\hline & $\begin{array}{l}\text { d } \\
(\mathrm{mm})\end{array}$ & Fy (N) & $\begin{array}{l}\Delta \mathrm{L}-\mathrm{y} \\
(\mathrm{mm})\end{array}$ & Fu $(\mathbf{N})$ & $\Delta \mathbf{L}-\mathbf{u}(\mathbf{m m})$ \\
\hline 1 & 1,42 & 11700 & 4,20 & 15500 & 6,50 \\
\hline 2 & 1,40 & 11300 & 4.10 & 15600 & 6,20 \\
\hline 3 & 1.35 & 10900 & 4,68 & 14900 & 6,70 \\
\hline 4 & 1,35 & 11500 & 4,00 & 15400 & 6,90 \\
\hline 5 & 1,40 & 12600 & 4,20 & 16300 & 7,30 \\
\hline 6 & 1,43 & 11300 & 4,15 & 15700 & 6,75 \\
\hline 7 & 1,48 & 11700 & 4,15 & 15400 & 6,79 \\
\hline 8 & 1,32 & 10800 & 4,00 & 14900 & 6.85 \\
\hline 9 & 1,40 & 11300 & 4,40 & 14600 & 7,40 \\
\hline 10 & 1,30 & 12800 & 4,60 & 15600 & 7,20 \\
\hline Rata2 & 1,39 & 11590 & 4,27 & 15390 & 6,86 \\
\hline
\end{tabular}

\section{A. Pengolahan Data dan Statistik}

a) Kekerasan Brinell

a) Luas Penampang $\mathrm{A}_{0}=\frac{\pi}{4} \cdot 8^{2}=50,24 \mathrm{~mm}^{2}$.

b) Tegangan Yield (yield stress) :

$$
\sigma_{\mathrm{y}}=\frac{F_{y}}{A_{0}}=\frac{11500}{50,24} \quad=228,90 \mathrm{~N} / \mathrm{mm}^{2}
$$

c) Regangan Luluh $\varepsilon$-y $(\%)=(\Delta \mathrm{L}-\mathrm{y}) / \mathrm{Lo}=4.30 / 75=5,73 \%$

d) Modulus Kekakuan $\quad \mathrm{E}=\sigma \mathrm{y} / \varepsilon-\mathrm{y}=228,90 / 0.0573=$ 3.992,44 $\mathrm{MPa}$

e) Tegangan Ultimate (ultimate stress) :

$$
\sigma_{\mathrm{u}}=\frac{\mathrm{F}_{\mathrm{u}}}{\mathrm{A}_{0}}=\frac{15800}{50,24} \quad=314,49 \mathrm{~N} / \mathrm{mm}^{2}
$$

Dengan cara yang sama data yang lain dapat dihitungdan hasilnya ditabelkan sebagai berikut 


\section{B. Hasil Pengolahan Data Penelitian}

Tabel 3. Hasil Perhitungan Penelitian Baja Silindris

\begin{tabular}{|l|l|l|l|l|l|}
\hline \multirow{2}{*}{ Sp } & \multicolumn{5}{|c|}{ Nilai Kekerasan,Tegangan Luluh, Regangan, } \\
\cline { 2 - 6 } & Modulus Kekakuan dan Tegangan Ultimate \\
\hline 1 & 139,5 & 334,70 & 6,12 & $4.970,50$ & 474,80 \\
\hline 2 & 140,7 & 335,60 & 7,13 & $5.154,45$ & 480,60 \\
\hline 3 & 148,5 & 340,20 & 6,20 & $5.385,40$ & 495,40 \\
\hline 4 & 145,0 & 335,20 & 6,70 & $5.485,85$ & 480,80 \\
\hline 5 & 135,5 & 345,80 & 7,00 & $5.380,60$ & 490,90 \\
\hline 6 & 142,3 & 336,00 & 7,10 & $4.840,50$ & 490,70 \\
\hline 7 & 148,8 & 338,10 & 6,90 & $5.350,25$ & 466,30 \\
\hline 8 & 141,3 & 325,20 & 7,23 & $5.448,50$ & 490,70 \\
\hline 9 & 137,1 & 338,10 & 7,50 & $5.980,40$ & 458,30 \\
\hline 10 & 142,2 & 333,80 & 6,78 & $5.890,15$ & 475,30 \\
\hline Rata2 & $\mathbf{1 4 2 , 0 9}$ & $\mathbf{3 3 6 , 2 7}$ & $\mathbf{6 , 8 7}$ & $\mathbf{5 3 8 8 , 6 6}$ & $\mathbf{4 7 8 , 7 1}$ \\
\hline
\end{tabular}

Tabel 3. Hasil Perhitungan Penelitian Baja Pelat

\begin{tabular}{|c|c|c|c|c|c|}
\hline \multirow{2}{*}{ Sp } & \multicolumn{5}{|c|}{$\begin{array}{l}\text { Nilai Kekerasan,Tegangan Luluh, Regangan, } \\
\text { Modulus Kekakuan dan Tegangan Ultimate }\end{array}$} \\
\hline & HBN & $\begin{array}{l}\sigma \mathrm{y} \\
(\mathbf{M P a})\end{array}$ & $\begin{array}{l}\varepsilon-y \\
(\%)\end{array}$ & E (MPa) & $\sigma \mathrm{u}(\mathrm{MPa})$ \\
\hline 1 & 112,4 & 228,90 & 5,52 & $3.990,40$ & 380,40 \\
\hline 2 & 113,5 & 235,50 & 6,40 & $4.096,51$ & 375,50 \\
\hline 3 & 113,5 & 225,40 & 5,90 & $4.295,33$ & 384,22 \\
\hline 4 & 120,7 & 228,60 & 5,98 & $4.196,37$ & 374,34 \\
\hline 5 & 120,9 & 230,80 & 6,10 & $4.398,74$ & 384,28 \\
\hline 6 & 112,8 & 225,30 & 6,32 & $3.393,49$ & 384,24 \\
\hline 7 & 116,5 & 230,20 & 5,99 & $4.392,73$ & 370,22 \\
\hline 8 & 118,3 & 228,30 & 6,10 & $4.490,32$ & 394,87 \\
\hline 9 & 115,3 & 230,30 & 6,52 & $3.997,23$ & 360,50 \\
\hline 10 & 116,4 & 230,70 & 5,50 & $3.890,67$ & 375,80 \\
\hline Rata2 & 115,99 & 229,4 & 6,03 & 4114,18 & 378,44 \\
\hline
\end{tabular}

C. Grafik Perbandingan Hasil Penelitian Speimen Baja Silindris dan Baja Pelat

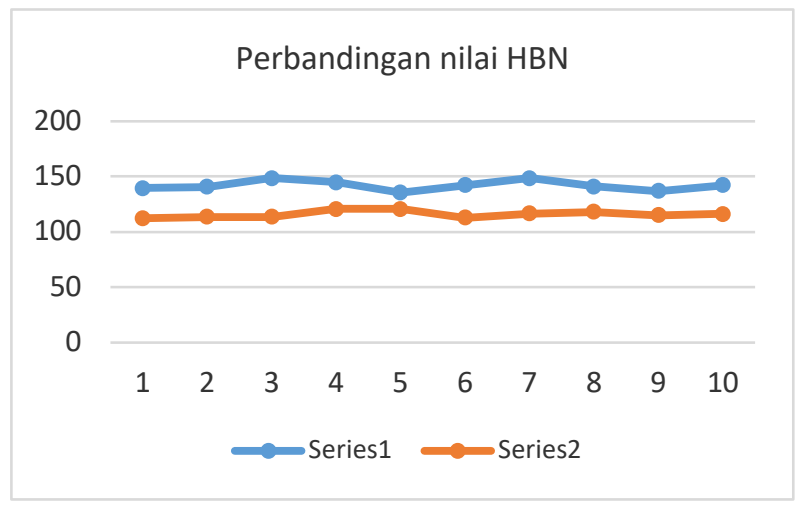

Gambar 5. Grafik perbandingan nilai HBN

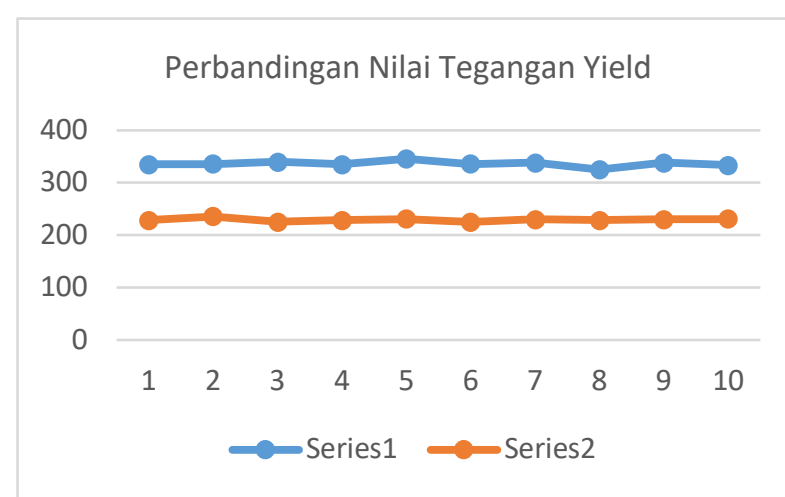

Gambar 6. Grafik Perbandingan Nilai Tegangan Yield

Perbandingan Nilai Regangan

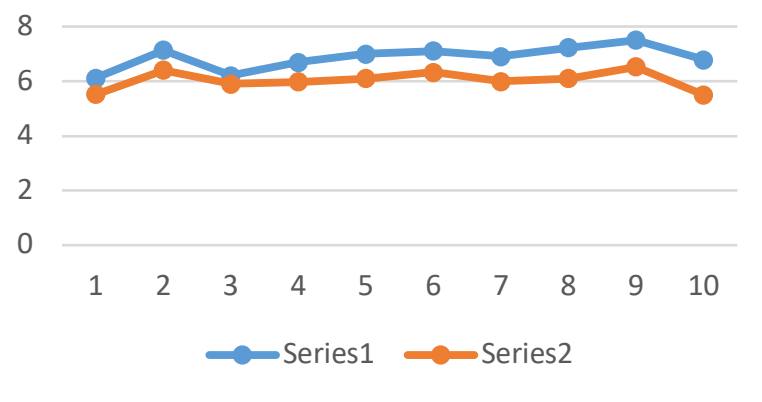

Gambar 7. Grafik Perbandingan Nilai prosentase Regangan

Perbandingan Nilai Modulus Elastisitas

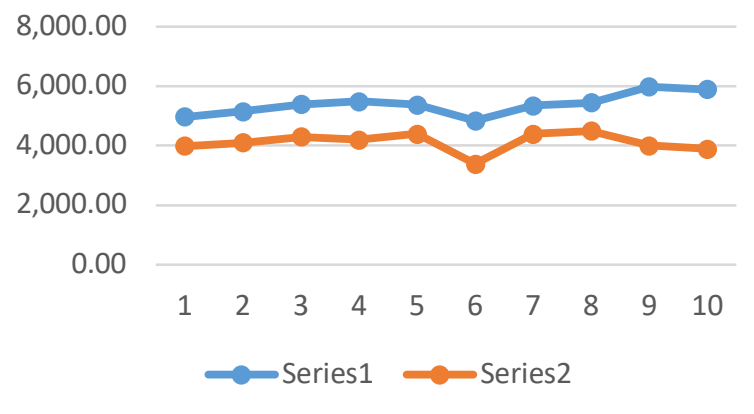

Gambar 8. Grafik Perbandingan Nilai Modulus Elastisitas

Perbandingan Nilai Tegangan Ultimate

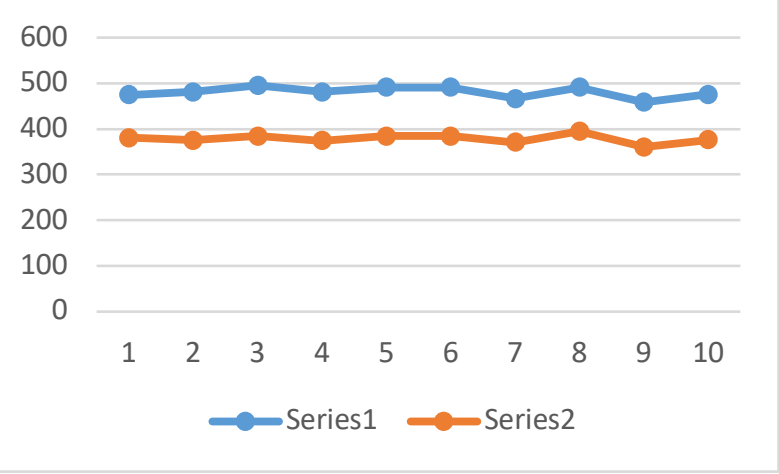

Gambar 9. Grafik Perbandingan Nilai Tegangan Ultimate 
Hasil Perhitungan Rasio (Konstanta Kesebandingan):

\begin{tabular}{|c|c|c|}
\hline Ro & $\sigma y / \sigma u$ & $=$ \\
\hline Ry & $\sigma y / H B N$ & $=$ \\
\hline $\mathrm{Ru}$ & $\sigma \mathrm{u} / \mathrm{HBN}$ & $=$ \\
\hline $\mathrm{RE}$ & E/HBN & $=$ \\
\hline
\end{tabular}

Tabel Konstanta Kesebandingan

a).Tabel Konstanta Kesebandingan Spesimen Baja Silindris

\begin{tabular}{|l|l|l|l|l|}
\hline Spesimen & Ro & Ry & Ru & RE \\
\hline 1 & 0,820 & 2,53 & 3,35 & 56,60 \\
\hline 2 & 0,835 & 2,50 & 3,28 & 56,25 \\
\hline 3 & 0,820 & 2,46 & 3,45 & 58,56 \\
\hline 4 & 0,830 & 2,40 & 3,30 & 57,30 \\
\hline 5 & 0,819 & 2,24 & 3,40 & 58,60 \\
\hline 6 & 0,810 & 2,38 & 3,32 & 56,49 \\
\hline 7 & 0,850 & 2,47 & 3,51 & 57,27 \\
\hline 8 & 0,840 & 2,35 & 3,34 & 57,34 \\
\hline 9 & 0,828 & 2,37 & 3,41 & 56,69 \\
\hline 10 & 0,830 & 2,41 & 3,44 & 57,66 \\
\hline Rata2 & $\mathbf{0 , 8 3 0}$ & $\mathbf{2 , 4 1}$ & $\mathbf{3 , 3 8}$ & $\mathbf{5 7 , 2 8}$ \\
\hline
\end{tabular}

b) Tabel Konstanta Kesebandingan Spesimen Baja Pelat

\begin{tabular}{|l|l|l|l|l|}
\hline Spesimen & $\mathbf{R o}$ & $\mathbf{R y}$ & $\mathbf{R u}$ & $\mathbf{R E}$ \\
\hline 1 & 0,742 & 2,40 & 3,30 & 41,87 \\
\hline 2 & 0,730 & 2,29 & 3,19 & 42,50 \\
\hline 3 & 0,728 & 2,42 & 3,33 & 42,60 \\
\hline 4 & 0,730 & 2,36 & 3,18 & 43,25 \\
\hline 5 & 0,729 & 2,15 & 3,39 & 43,90 \\
\hline 6 & 0,737 & 2,25 & 3,12 & 43,63 \\
\hline 7 & 0,740 & 2,33 & 3,42 & 42,43 \\
\hline 8 & 0,750 & 2,26 & 316 & 42,51 \\
\hline 9 & 0,738 & 2,57 & 3,31 & 41,90 \\
\hline 10 & 0,730 & 2,43 & 3,27 & 43,84 \\
\hline Rata2 & $\mathbf{0 , 7 3 5}$ & $\mathbf{2 , 3 5}$ & $\mathbf{3 4 , 5 5}$ & $\mathbf{4 2 , 8 4}$ \\
\hline
\end{tabular}

c) Tabel: Hasil regresi dengan bantuan SPSS Variables Entered/Removed(b)

\begin{tabular}{|l|l|l|l|}
\hline Model & $\begin{array}{l}\text { Variables } \\
\text { Entered }\end{array}$ & $\begin{array}{l}\text { Variables } \\
\text { Removed }\end{array}$ & Method \\
\hline 1 & Regangan(a) & & Enter \\
\hline
\end{tabular}

a All requested variables entered.

b Dependent Variable: Kekerasan

Model Summary

\begin{tabular}{|l|l|l|l|l|}
\hline $\begin{array}{l}\text { Mod } \\
\mathrm{el}\end{array}$ & $\mathrm{R}$ & $\begin{array}{l}\text { R } \\
\text { Square }\end{array}$ & $\begin{array}{l}\text { Adjusted R } \\
\text { Square }\end{array}$ & $\begin{array}{l}\text { Std. Error of the } \\
\text { Estimate }\end{array}$ \\
\hline 1 &, $174(\mathrm{a}$ &, 030 &,- 455 & 1,80907 \\
\hline
\end{tabular}

a Predictors: (Constant), Regangan
ANOVA(b)

\begin{tabular}{|l|l|r|r|r|r|r|}
\hline \multicolumn{2}{|l|}{ Model } & $\begin{array}{l}\text { Sum of } \\
\text { Squares }\end{array}$ & df & $\begin{array}{l}\text { Mean } \\
\text { Square }\end{array}$ & F & Sig. \\
\hline \multirow{2}{*}{1} & Regression &, 205 & 1 &, 205 &, 063 &, $826(\mathrm{a})$ \\
\cline { 2 - 8 } & Residual & 6,545 & 2 & 3,273 & & \\
\cline { 2 - 7 } & Total & 6,750 & 3 & & & \\
\hline
\end{tabular}

a Predictors: (Constant), Regangan

b Dependent Variable: Kekerasan

Coefficients(a)

\begin{tabular}{|c|c|c|c|c|c|c|}
\hline \multirow{2}{*}{\multicolumn{2}{|c|}{ Model }} & \multicolumn{2}{|c|}{$\begin{array}{l}\text { Unstandardize } \\
\text { d Coefficients }\end{array}$} & \multirow{2}{*}{$\begin{array}{l}\text { Standardized } \\
\text { Coefficients } \\
\text { Beta } \\
\end{array}$} & \multirow{2}{*}{$\mathrm{t}$} & \multirow{2}{*}{$\begin{array}{l}\text { Sig. } \\
\text { Std. } \\
\text { Error }\end{array}$} \\
\hline & & B & $\begin{array}{l}\text { Std. } \\
\text { Error }\end{array}$ & & & \\
\hline \multirow[t]{2}{*}{1} & (Constant) & $\begin{array}{r}160,0 \\
00\end{array}$ & 3,133 & & $\begin{array}{c}51, \\
063\end{array}$ &, 000 \\
\hline & Regangan & $\begin{array}{r}- \\
27,27 \\
3\end{array}$ & $\begin{array}{r}109,0 \\
91\end{array}$ &,- 174 & $\begin{array}{r}- \\
, 25 \\
0\end{array}$ & ,826 \\
\hline
\end{tabular}

a Dependent Variable: Kekerasan

\section{Analisa Pembahas}

Kekerasan material untuk baja silindris rata-rata sebesar 142,09 dan untuk baja pelat sebesar 115,99 HBN.

Sewaktu logam mengalami tarikan terjadi perubahan struktur butir, terjadi perpecahan butir, pergeseran atom dan distorsi kisi. Dengan adanya deformasi butir maka tahanan terhadap doformasi meningkat sehingga mengalami peningkatan kekuatan dan kekerasan.

1) Tabel variabel entered menunjukan bahwa tidak ada variabel dikeluarkan (removed), dengan kata lain kedua variabel dimasukkan dalam perhitungan regresi.

2) Standar error of estimate adalah 1.8 untuk regangan.

3) Uji Anova atau $F$ test diperoleh $F$ hitung adalah 0.65 dengan tingkat signifikanisasi 0,05 dan model regresi bisa dipakai untuk memprediksi pengaruh factor regangan yang terjadi.

4) Tabel rasio menggambarkan persamaan regresi $\mathrm{Y}=2,41 \mathrm{X} 1-0,4347 \mathrm{X} 2$ (Baja Silindris) $\mathrm{Y}=2,35 \mathrm{X} 1-0,534 \mathrm{X} 2$ (Baja Pelat))

Dimana Y adalah kekerasan

$\mathrm{X} 1=$ harga kekerasan skala

$\mathrm{X} 2$ = perubahan regangan yang timbul

\section{KESIMPULAN}

\section{A. Simpulan}

Dari hasil pengujian dan pengolahan data serta pembahasan disimpulkan beberapa hal berikut ini:

1) Persamaann regresi yang dihasilkan untuk baja silndris $Y$ $=2,41 \mathrm{X} 1-0,4347 \mathrm{X} 2$ dan untuk specimen baja pelat (rata) $\mathrm{Y}=2,35 \mathrm{X} 1-0,534 \mathrm{X} 2$.

2) Formulasi hubungan merupakan bentuk persamaan yang berbanding lurus dengan konstanta sebesar 2,41 dan 2,35 dikurangi faktor 0,4347 dan 2,35 X faktor regangan yang dialaminya.

3) Formulasi diatas menjelaskan bahwa nilai batas elastisitas 2,41 X HBN (Baja Silindris) dan 2,35 X HBN (Baja Pelat) masing-masing dikurang dengan pegaruh factor regangannya.

B. Saran

1. Sebaiknya jumlah data yang diambil bisa lebih banyak 
2. Pengujian lain, misalnya uji buckling, bending dan puntir perlu dilaksanakan untuk evaluasi kekakuan material secara lebih lengkap.

3. Pengaruh dominan dan penyimpangan yang terjadi sebaiknya dijelaskan lebih rinci lagi secara statistik.

\section{DAFTAR PUSTAKA}

[1] Amstead, BH. (1995). Teknologi Mekanik edisi 7 versi SI, Erlangga

[2] ------------ (1979). Manufacturing Processes, Publishing simultance in Canada

[3] Http://www.twi.co.uk, Mesin Uji Tarik

[4] Http://www.info.lu.farningadale.edu, Uji tarik

[5] Jensen, Alfred dan Harry H. Chenoweth. (1991) Kekuatan Bahan Terapan. Terjemahan Darwin Sebayang. Jakarta: Erlangga.

[6] Khurmi, R.S. dan J.K. Gupta (1992) A Text Book of Machine Design. Eurasia Publishing House New Delhi:

[7] Murdani, Anggit (2012). Praktek Uji Bahan, Polinema

[8] Purwanto, Edy (2012) Teknologi Bahan, Polinema

[9] Singer, Ferdinand L. dan Andrew Pytel. (1995) Ilmu Kekuatan Bahan.. Terjemahan Darwin Sebayang. Jakarta: Erlangga.

[10] Sudjana. (1992) Metoda Statistik, edisi 5, Erlangga

[11] Viyus, Vinan, 2005, Mekanika Teknik II. Buku Ajar Jurusan Teknik Mesin Polinema.

[12] --------------, 2011 Pengaruh Pasca Bending Terhadap Kekuatan Tarik Baja Strip, Prosiding Sentia

[13] William F Smith. (1990), Priciples of Material Sience and Engineering. Mc Graw-Hill Bok Company Singapore.

[14] Zainuri, A Muhib. (2009), Kekuatan Bahan. Andi Offset, Yogyakarta

\section{SIMBOL}

$\sigma:$ Satuan tegangan atau tegangan $\left(\mathrm{N} / \mathrm{mm}^{2}\right)$.

F : Gaya yang bekerja pada benda $(\mathrm{N})$.

A: Luas penampang benda $\left(\mathrm{mm}^{2}\right)$.

$\Delta \mathrm{L}$ : Pertambahan Panjang akibat tarikan ( $\mathrm{mm})$

бy Tegangan Luluh (MPa)

бu: tegangan Ultimate ( MPa)

$\varepsilon$-y: Regangan Tarik

$\mathrm{E}$ : Modulus Elastisitas Bahan (MPa)

HBN: Nilai kekrasan Brinell

Yij :nilai pengamatan ke i dalam kelompok j

$\mu$ : nilai rata-rata umum

ai : pengaruh perlakuanke i

eij : kesalahan percobaan pada perlakuan ke I ulangan

ke $\mathrm{j}$ Output yang diperoleh berupa gaya dan pertambahan panjang akibat penarikan. 